\title{
Response of deep-sea scavengers to ocean acidification and the odor from a dead grenadier
}

\author{
James P. Barry ${ }^{1, *}$, Jeffrey C. Drazen ${ }^{2}$ \\ ${ }^{1}$ Monterey Bay Aquarium Research Institute, 7700 Sandholdt Road, Moss Landing, California 95039, USA \\ ${ }^{2}$ University of Hawaii, Department of Oceanography, MSB 606, 1000 Pope Rd, Honolulu, Hawaii 96822, USA
}

\begin{abstract}
Experiments to assess the impact of ocean acidification on abyssal animals were performed off Central California. The survival of caged megafauna (Benthoctopus sp., Pachycara bulbiceps, Coryphaenoides armatus) exposed to $\mathrm{CO}_{2}$-rich and normal (control) seawater varied among species. Benthoctopus sp. and $P$. bulbiceps survived control conditions and month-long episodic exposure to acidic, $\mathrm{CO}_{2}$-rich waters ( $\mathrm{pH}$ reductions of $\sim 0.1 \mathrm{U}$ ). All C. armatus in both treatments died, potentially due to cage-related stress, predation, and exposure to acidic waters. High survival by $P$. bulbiceps and Benthoctopus under month-long exposure to $\mathrm{CO}_{2}$-rich waters indicates a physiological capacity to cope, at least temporarily, with stresses that will accompany expected future changes in ocean chemistry. The abundance of free-ranging scavengers was not correlated with variation in $\mathrm{pH}$ levels near fish cages. Incidental observations of abyssal scavengers collected using time-lapse cameras during these experiments were used secondarily to evaluate the hypothesis that macrourid fishes avoid the odor of dead conspecifics. Caged macrourids in view of time-lapse cameras died within 2 to $3 \mathrm{~d}$, eliciting a strong response from the regional scavenger assemblage which aggregated near the cage. The pattern of scavenger visits suggests avoidance among taxa and a succession of scavengers. Macrourids, a dominant abyssal scavenger, either did not respond to the death of their congener or possibly avoided the area. Lack of a response by macrourids may be due to (1) avoidance of sites of dead or dying congeners, (2) high sensitivity to ocean acidification, (3) low nutritional value or weaker odor plumes from carcasses of abyssal versus shallow-water taxa, or (4) rapid departure from sites where a carcass is inaccessible. Camera systems were not deployed in view of carcasses at control sites (away from $\mathrm{CO}_{2}$ pools) during each experiment, and we therefore cannot exclude the possibility that the pattern of scavenger visits was influenced by elevated carbon dioxide levels.
\end{abstract}

KEY WORDS: Food fall - Behavior - Macrouridae - Coryphaenoides armatus - Zoarcidae · Pachycara bulbiceps $\cdot$ Octopodidae $\cdot$ Benthoctopus sp.

\section{INTRODUCTION}

The rise in ocean $\mathrm{CO}_{2}$ levels due to the passive flux of carbon dioxide through the air-sea boundary is causing rapid and dramatic change in the carbonate chemistry of the oceans. Higher carbon dioxide levels react with the carbonate chemistry of seawater to increase ocean acidity. Rising ocean carbon levels have caused the $\mathrm{pH}$ of ocean surface waters to drop by $0.1 \mathrm{U}$ in only the past $50 \mathrm{yr}$ (Caldeira \& Wickett 2003). Anthropogenic carbon dioxide is now detectable to ocean depths of 1 to $3 \mathrm{~km}$, as the surface carbon signal penetrates slowly into the deep sea (Sabine et al. 2004). Deep-ocean carbon sequestration, a concept considered to mitigate the rapid rise in atmospheric carbon levels, could also result in severe acidification of deep-sea waters, at least near disposal sites (Shirayama 1998). Projections of future ocean carbon levels indicate a reduction in surface ocean $\mathrm{pH}$ of $0.4 \mathrm{U}$ by 2100 , and may reach $-1.0 \mathrm{U}$ over the next few centuries (Caldiera \& Wickett 2003). This signal will mix and propagate through the water column and could 
have a significant impact on ocean ecosystems (Orr et al. 2005, Raven et al. 2005). $\mathrm{CO}_{2}$-related stresses for ocean organisms exposed to $\mathrm{CO}_{2}$-rich, acidic waters include reduced calcification, respiratory stress, disruption of the acid-base balance, and metabolic depression (Pörtner et al. 2004a). The severity of $\mathrm{CO}_{2}$ related stress is expected to be considerably greater for deep-sea organisms (Seibel \& Walsh 2001), but little research has addressed this issue directly.

In the current paper we present results from a series of field experiments off Central California to evaluate the tolerance of abyssal animals to elevated $\mathrm{CO}_{2}$ levels. We focus on a few species of common abyssal scavengers (the octopus Benthoctopus sp. [Octopodidae], the eelpout Pachycara bulbiceps [Zoarcidae], and the grenadier Coryphaenoides armatus [Macrouridae]), which were captured in baited cages, then held in $\mathrm{CO}_{2}$-rich, acidic waters and in control locations during month-long experiments. Although the sensitivity of the 2 abyssal fishes to ocean acidification is not known, some information is available concerning the behavioral and physiological responses of deep-sea megafauna to elevated carbon dioxide levels. Seibel \& Walsh (2003) showed that moderate ( $-0.3 \mathrm{pH} \mathrm{U})$ acidosis of the blood of Benthoctopus sp. reduced oxygen binding by hemocyanin by $40 \%$. Pachycara brachycephalum, a bathydemersal congener of $P$. bulbiceps, undergoes a $\sim 35 \%$ reduction in oxygen consumption in cell suspensions with a $0.6 \mathrm{U}$ pH reduction (Langenbuch \& Pörtner 2003), but little is known of the response of live animals. Tamburri et al. (2000) evaluated the response of bathyal scavengers exposed to $\mathrm{CO}_{2}$-rich waters or filtrate from homogenized shallow water fishes or both, finding that various scavengers were attracted strongly to the food odor, even with the strong narcotizing effects of the $\mathrm{CO}_{2}$-rich plume. For smaller abyssal organisms, our previous results have shown that sediment-dwelling meiofauna experience significant mortality after month-long exposure to $\mathrm{pH}$ reductions of $\sim 0.1$ to $0.3 \mathrm{U}$ (Barry et al. 2004, Thistle et al. 2005).

A secondary focus of the present paper, based on incidental time-lapse observations of the abyssal scavenger assemblage collected during these ocean acidification experiments, was to evaluate the behavioral response of abyssal scavengers to the odor plume from dead macrourid fishes. Following the unexpected death of Coryphaenoides armatus held in cages during ocean acidification studies, we observed the response of the scavenger assemblage to these 'food falls'.

A variety of factors influence the scavenger assemblage observed in baited camera studies. Scavenger assemblages vary by region, with decreasing species richness with depth (Priede \& Bagley 2000, King et al. 2006), and respond variably to the type, size, and posi- tion of bait (Wolff 1976, Rowe et al. 1986, Armstrong et al. 1991, Witte 1999, Bailey et al. 2002, Kemp et al. 2006). At bathyal depths, megafaunal invertebrates are important scavengers (e.g. Smith 1985, Witte 1999), while at abyssal depths lysianassid amphipods and macrourid fishes are among the first and most abundant scavengers to arrive at food falls (Isaacs \& Schwartzlose 1975, Priede et al. 1991, Jones et al. 1998, Priede \& Bagley 2000). Bait used in time-lapse camera studies typically consists of shallow-water fishes or occasionally plants, and has ranged widely in size from single mackerel (Priede et al. 1994, Smith et al. 1997) to cetacean carcasses (Witte 1999, Smith et al. 2003, Kemp et al. 2006). Small to medium food falls are typically consumed within hours (Priede et al. 1994, Jones et al. 1998), resulting in a pattern of scavenger arrival and departure related to foraging behavior (Bailey \& Priede 2002).

Although grenadiers (Macrouridae) are common abyssal scavengers, their response to the odor plume from congeners or conspecifics is known poorly, since nearly all available studies have used shallow-water plants or animals as bait (but see Lampitt et al. 1983). Unlike the odor plume from sunken carcasses of shallow-water species, the scent from a dying or dead conspecific may indicate a potentially dangerous site, and it may be adaptive for benthic scavengers such as grenadiers to ignore or avoid such odors. Although the cause of death is likely indeterminable from the odor plume, recent mortality may indicate elevated risk of mortality for conspecifics, such as the presence of predators or risk of infectious disease. Thus, a balance between risk of starvation and predation or infection may influence scavenger behavior (McKillup \& McKillup 1992, 1994). Increased fitness associated with avoidance of sites with higher than average rates of injury or death may have led to selection for behavioral responses to remote cues indicative of increased risk. For example, elevated risk of mortality appears to reduce the abundance of vulnerable life-history phases (juveniles \& brooding females) of the lysianassid amphipod Orchomene nanus to food falls (Moore \& Wong 1995). Aversion to odor plumes from dying or recently dead conspecifics, as observed in several epibenthic scavengers (Moore \& Howarth 1996), may be an evolutionarily derived adaptation to reduce exposure to potential sources of mortality. In the present paper we describe the pattern of scavenger visits in response to odor plumes from dead grenadiers, and consider the hypothesis that macrourids are averse to the odor of dead or dying conspecifics.

The goals of the experiments described in this paper focused primarily on the effects of ocean acidification on abyssal scavenger species. Unplanned observations of the response of the scavenger assemblage to the 
Table 1. Summary of $\mathrm{CO}_{2}$-tolerance experiments and time-lapse observations. Start and end: dates for the initiation and termination of each experiment; TL: length in days of the time-lapse observations. The number of fish traps (cages) and distances (m) from $\mathrm{CO}_{2}$ pools are also listed

\begin{tabular}{|lcccccrrr|}
\hline Expt & $\begin{array}{c}\text { Latitude } \\
\left({ }^{\circ} \mathrm{N}\right)\end{array}$ & $\begin{array}{c}\text { Longitude } \\
\left({ }^{\circ} \mathrm{W}\right)\end{array}$ & $\begin{array}{c}\text { Depth } \\
(\mathrm{m})\end{array}$ & Start & End & $\begin{array}{c}\text { TL } \\
(\mathrm{d})\end{array}$ & $\begin{array}{c}\text { Cages } \\
\text { Distance } \\
(\mathrm{m})\end{array}$ \\
\hline E1 & 36.712 & 123.525 & 3600 & 2 Apr 2002 & 2 May 2002 & 24.8 & 8 & 1 to 50 \\
E2 & 36.712 & 123.525 & 3600 & 19 Dec 2003 & 19 Sep 2005 & 8.9 & 8 & 1 to 75 \\
E3 & 36.700 & 123.006 & 3100 & 13 Dec 2004 & 21 Jan 2005 & 8.6 & 0 & - \\
\hline
\end{tabular}

death of grenadiers held in cages for the acidification studies formed the basis for novel observations of scavenger behavior at an abyssal food fall. This study differs from typical food fall studies in 2 significant ways. First, the time-lapse observations focus on caged macrourids that did not produce an odor plume stimulating scavengers until their death 3 to $4 \mathrm{~d}$ into the observations. In addition, the attractant was the odor from a decaying macrourid, rather than a shallowwater species.

\section{MATERIALS AND METHODS}

Effects of ocean acidification. A series of approximately month-long experiments (E1, E2, E3) used to evaluate the tolerance of abyssal scavengers to ocean acidification was performed at 3100 to $3600 \mathrm{~m}$ depth on the flat, relatively featureless seabed of the continental rise off Central California (E1 \& E2: $36.712^{\circ} \mathrm{N}$, 123.525 $5^{\circ} \mathrm{W}, \mathrm{E} 3: 36.7^{\circ} \mathrm{N}, 123.006^{\circ} \mathrm{W}$, Fig. 1a, Table 1). During 2 experiments (E1, E2) demersal and benthopelagic scavengers (Macrouridae, Coryphaenoides

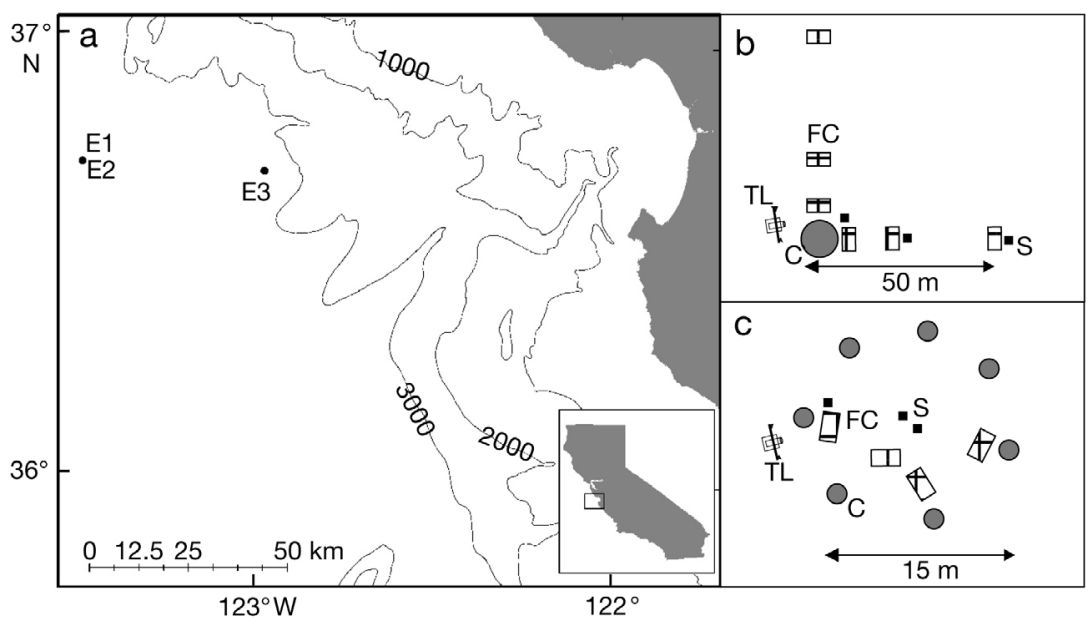

Fig. 1. (a) Study sites off Central California, 3100 and $3600 \mathrm{~m}$ depth. Contour depths in meters. (b) Experimental layout for the position of $\mathrm{CO}_{2}$ pools, caged animals, and sensors in E1. (c) Experimental layout for $\mathrm{CO}_{2}$ treatment area in

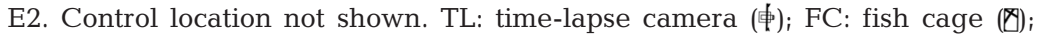
$\mathrm{C}: \mathrm{CO}_{2}$ pool (O); S: sensor ( $\square$ armatus; Zoarcidae, Pachycara bulbiceps; Octopodidae, Benthoctopus sp.) were held in cages positioned at sites with $\mathrm{CO}_{2}$-rich, acidic waters (treatment) and control sites with normal ocean chemistry. Study animals were captured during a short period (1 to 2 d) prior to each experiment, in cages baited with mackerel or squid. At the start of each experiment, the cages were locked closed to prevent further ingress or egress. For E1, a small amount of bait remained in the cage and continued to attract scavengers, at least during the beginning of the experiment. In E2, the bait was removed prior to the start of the experiment to inhibit the attraction of additional scavengers. During E3, a time-lapse camera system was deployed to observe a $\mathrm{CO}_{2}$ corral and nearby area, but baited cages were not deployed to capture benthopelagic scavengers. Thus, no odor plume from dead or dying caged megafauna was present during this experiment, and time-lapse observations are more representative of the background densities of animals, particularly prior to injection of liquid $\mathrm{CO}_{2}$ into the corrals. The original purpose of these experiments was to assess the effects of hypercapnia on deep-sea benthos (Barry et al. 2005).

High $\mathrm{CO}_{2}$ conditions were created by releasing liquid carbon dioxide (20 to 100 l) into small corrals (sections of PVC pipe) placed on the seabed using the remotely operated vehicle (ROV) 'Tiburon', operated by the Monterey Bay Aquarium Research Institute. Because deep-ocean waters are undersaturated with carbon dioxide, the liquid $\mathrm{CO}_{2}$ dissolves slowly into seawater, forming a high- $\mathrm{CO}_{2}$, low-pH dissolution plume, which mixes with the ambient current and drifts downcurrent over sediments and any animals nearby.

The arrangement of the $\mathrm{CO}_{2}$ corrals varied. For E1, a single 1001 pool was created and caged animals were positioned from 0.5 to $50 \mathrm{~m}$ away (Fig. 1b). In $\mathrm{E} 2$ a circular pattern of $\mathrm{CO}_{2}$ pools ( $\mathrm{n}=7$ corrals) was used, with cages 
placed within the circle and at a control location $\sim 100$ $\mathrm{m}$ away (Fig. 1c). During E3, $\mathrm{CO}_{2}$ corrals were configured similar to E2 (Fig. 1c), using 14 corrals, and no fish cages. At the end of these month-long experiments, we compared the survival of treatment (high $\mathrm{CO}_{2}$ ) and control (normal $\mathrm{CO}_{2}$ ) groups.

Physical conditions, including the strength of the dissolution plume $(\mathrm{pH}$ changes were used as a proxy for $\mathrm{CO}_{2}$ levels) and variation in the speed and direction of bottom currents were measured by instruments deployed near cages and $\mathrm{CO}_{2}$ pools at the experimental sites. Conductivity, depth, and pressure were measured with CTDs (SeaBird Model 19+), which were each also equipped with 2 SeaBird Model $18 \mathrm{pH}$ sensors. These sensors, positioned at various distances from the animal cages and $\mathrm{CO}_{2}$ corrals during each experiment to measure variation in seawater chemistry, recorded the temperature, salinity, pressure, and $\mathrm{pH}$ at 5 min intervals throughout the experiment. $\mathrm{pH}$ sensors were positioned from 5 to $50 \mathrm{~cm}$ above the seabed to measure the potential spatial variation in the dissolution plume. Near-bottom currents were measured at 5 min intervals during each experiment using an acoustic doppler current meter (ADCP; RDI Sentinel, $600 \mathrm{mHz}$ ) mounted $2 \mathrm{~m}$ above the seabed, fixed in an upward-looking orientation. Measurements 7 m.a.b. (meters above bottom) were the records nearest the seabed and were used to characterize the local flow pattern. Although it would be preferable to measure flow nearer the seabed (e.g. 1 m.a.b.), this was not possible using the equipment available. Additional details of these experiments are available in Barry et al. (2005).

Time-lapse camera observations. A time-lapse imaging system was deployed during each experiment with a primary objective of observing rates of dissolution from $\mathrm{CO}_{2}$ pools and the behavior of caged animals under elevated $\mathrm{CO}_{2}$ levels. Observations of the behavior and abundance of scavengers in the vicinity of the cage before and after the death of caged macrourid fishes were incidental, but are the basis of the results presented below concerning factors influencing scavenger behavior. A single camera system was available, and it was positioned strategically to view at least part of a $\mathrm{CO}_{2}$ pool for observations of $\mathrm{CO}_{2}$ dissolution, and also in view of a cage (E1, E2) to observe animal behavior. Because scavenger observations were not an initial objective of these experiments, time-lapse observations were not made at control sites, and, thus, all time-lapse images are at $\mathrm{CO}_{2}$-treatment sites.

For E1, a monochrome, time-lapse video camera equipped with LED lights was positioned to view the $\mathrm{CO}_{2}$ pool and the nearest cage ( $\sim \mathrm{m}$ away) containing Coryphaenoides armatus $(\mathrm{n}=2)$ and Pachycara bulbiceps $(\mathrm{n}=1)$ (Fig. 2a). Video (Hi-8 format) was recorded in hourly intervals $\left(8 \mathrm{~s}_{\text {interval }}{ }^{-1}\right)$ from 4 April to 1 May 2002. For E2 and E3, a Seasnap 990 camera system equipped with twin $100 \mathrm{~mW}$ incandescent lights was used to obtain time-lapse images. During E2, the camera system was positioned to view a $\mathrm{CO}_{2}$ corral and a full, side-view of the closest cage (Fig. 2b,c). The cage, positioned $\sim 1 \mathrm{~m}$ from 1 of the $\mathrm{CO}_{2}$ corrals, contained C. armatus $(\mathrm{n}=1)$ and Benthoctopus sp. $(\mathrm{n}=1)$. Single digital images were captured every hour for $8.2 \mathrm{~d}$ from 21 to 29 August 2003, at which time the low battery power terminated the image sequence. For E3, the Seasnap system was positioned to view a $\mathrm{CO}_{2}$ corral and the nearby seabed (Fig. 2d). No caged animals were used during E3. Digital images were recorded every $2 \mathrm{~h}$ for $206 \mathrm{~h}$ from 14 to 23 December 2004.

The position and condition of the caged Coryphaenoides armatus, Pachycara bulbiceps, and Benthoctopus sp. were noted for each recording interval of E1 and E2. For E1, the position within the cage for $C$. armatus and $P$. bulbiceps was coded as 1 (top one-third of cage), 2 (middle one-third), and 3 (bottom one-third). For E2, the poorer quality of images restricted observations, and counts were made of the number of C. armatus and P. bulbiceps swimming in the top one-half of the cage. Spearman's rank correlation tests comparing the position of the 2 caged species for each experiment were performed using observations during the period prior to the death of the macrourids, and after their death when scavengers were present near the carcass.

Scavenger behavior. In addition to quantifying the position of animals within cages, all identifiable organisms observed in each image of the time-lapse series from each experiment were identified and counted. For Seasnap images (E2 \& E3) the identity of nearly all fishes and octopuses was clear, though for a few cases identification to the species level was questionable. Congeners of Coryphaenoides armatus and Pachycara bulbiceps live in the study region, but are quite rare. Therefore, we assumed that all macrourids observed were $C$. armatus and all large zoarcids were $P$. bulbiceps. This assumption is supported by collections of several individuals of each species during the studies. Due to image quality of the monochrome video system and the long exposure time (1 s) used for the Seasnap digital image system, small, rapidly moving objects were rarely identifiable, and appeared as small 'streaks' in images. Many of these objects could be benthopelagic scavengers such as lysianassid amphipods, but were not considered for analysis.

Observations of scavengers during each experiment were divided into several phases based on the shifting pattern of behavior or activity. The 'Pre-cage' period (Fig. 2b) preceding the placement of the cage in view of the camera (E2 only) was used to assess the background abundance of animals in the area. Observa- 

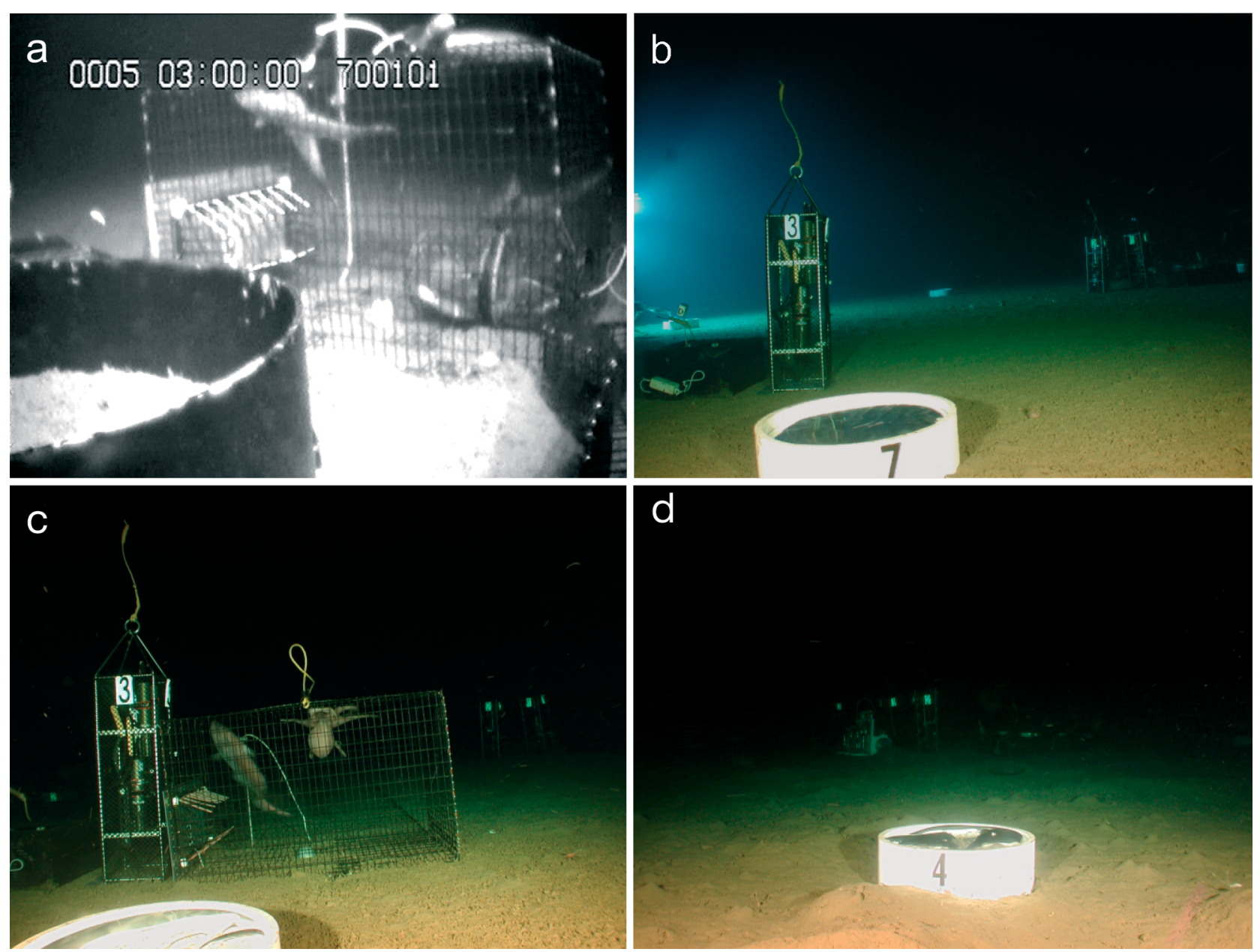

Fig. 2. Time-lapse images. (a) Monochrome image from time-lapse video during start of $\mathrm{E}$. $\mathrm{CO}_{2}$ corral (empty) visible at lower left, cage in background with 2 macrourids (Coryphaenoides armatus) and 1 zoarcid (Pachycara bulbiceps). (b) E2: pre-cage period (ROV lights providing extra light) $9 \mathrm{~h}$ after start. Pool of liquid $\mathrm{CO}_{2}$ just filled. (c) E2: live phase at $42 \mathrm{~h}$. (d) E3: Camera image focuses on $\mathrm{CO}_{2}$ corrals $(50 \mathrm{~cm}$ diameter). No baited traps were deployed for this experiment

tions in E3 were also categorized in this way. Activity in and around the caged animals shifted markedly from a 'Live' period (e.g. Figs. 2d \& 3a) prior to death of the caged macrourids to a 'Scavenging' phase (Fig. 3b,c) following their death. Large megafaunal scavengers were most active during the Scavenging phase, then dwindled in number during the 'Consumed' phase (Fig. 3d). During the Consumed phase, lysianassid amphipods and other small scavengers continued to consume the carcasses, but these scavengers were not clearly visible in time-lapse images.

The percentage frequency of occurrence of each organism observed was compared between periods, and Spearman's rank correlation coefficients were calculated for some pairs of species between Live and Scavenging periods to assess potential avoidance or aggregation. Correlation analyses were used to evaluate the hypothesis that scavenger abundance declined with higher $\mathrm{CO}_{2}$-related stress, as measured by $\mathrm{pH}$ reductions. Thus, we calculated correlation coefficients between observed $\mathrm{pH}$ and the abundance of common scavenger species for each experiment.

\section{RESULTS}

\section{Physical conditions}

Near-bottom currents were similar among sites and experiments. Conditions measured during E2 are presented here to represent flow at all sites. Currents $7 \mathrm{~m}$ above the seabed were variable in direction and in speed, but always quite sluggish. Flow varied from 0 to $8.7 \mathrm{~cm} \mathrm{~s}^{-1}$, with an average of $3 \mathrm{~cm} \mathrm{~s}^{-1}$ during timelapse observations. Net flow varied among experiments, but flow direction typically oscillated greatly, and generally rotated with the semidiurnal tides (Barry et al. 2005). 

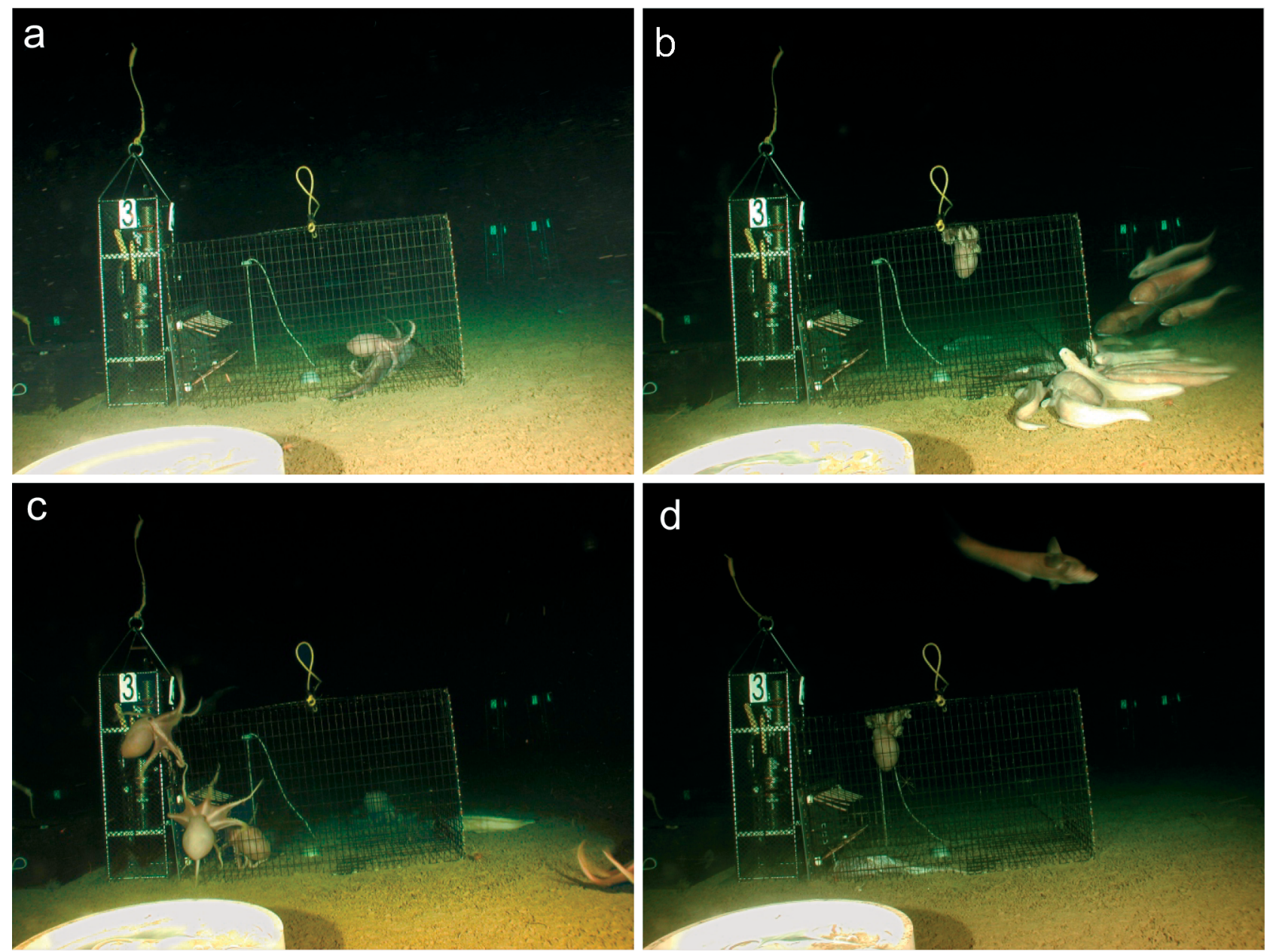

Fig. 3. Time-lapse images. (a) E2: Benthoctopus sp. attacks macrourid $73 \mathrm{~h}$ after start. (b) E2: Scavenger aggregation $114 \mathrm{~h}$ after start. (c) E2: Benthoctopus sp. aggregation $139 \mathrm{~h}$ after start. (d) E2. Coryphaenoides armatus carcass consumed, $180 \mathrm{~h}$ after start

The severity and persistence of $\mathrm{CO}_{2}$ treatments were similar among experiments and distance from $\mathrm{CO}_{2}$ pools, as recorded by sensors near caged animals. Dissolution of liquid $\mathrm{CO}_{2}$ pools was slow, apparently due to the sluggish bottom currents at the sites (Barry et al. 2005), producing only mild reductions in $\mathrm{pH}$. During E1, pH perturbations were episodic and short-lived, ranging from 0 to $-0.3 \mathrm{U}$ at a distance of $5 \mathrm{~m}$ from the large $\mathrm{CO}_{2}$ pool (Fig. 4a). The largest $\mathrm{pH}$ changes were measured during the latter half of the experiment, after the $\mathrm{CO}_{2}$ corral was refilled with liquid $\mathrm{CO}_{2}$. pH sensors within $0.5 \mathrm{~m}$ of the large $\mathrm{CO}_{2}$ corral failed, but measurements close to $\mathrm{CO}_{2}$ corrals in other experiments have shown $\mathrm{pH}$ reductions $>1 \mathrm{U}$.

During E2, pH changes in the center of the circle of $\mathrm{CO}_{2}$ corrals were also episodic and milder than in E1 (Fig. 4b). Variation in pH was greatest during the first 3 to $4 \mathrm{~d}$ of E2 (Live phase), with occasional excursions greater than $-0.15 \mathrm{U}$. After this period, $\mathrm{pH}$ variability was low and average values were near (within $\sim 0.05 \mathrm{U}$ ) ambient. The $\mathrm{CO}_{2}$ corrals were not refilled during E2, and much of the liquid carbon dioxide had dissolved by the end of the month-long experiment. The pattern of $\mathrm{pH}$ variability during E3 (not shown) was very similar to that during E2.

\section{Effects of $\mathrm{CO}_{2}$ treatments}

There was no detectable response by caged or freeranging megafauna after a month-long exposure to the mild acidic dissolution plume emanating from pools of liquid $\mathrm{CO}_{2}$. All caged Benthoctopus sp. and Pachycara bulbiceps survived at both the $\mathrm{CO}_{2}$-treatment and control locations. In contrast, all caged Coryphaenoides armatus died, regardless of treatment. The abundances of free-ranging scavengers, either overall (total scavenger abundance) or for individual species, were not correlated to $\mathrm{pH}$ measured near caged fishes during E1 or E2. 
Fig. 4. Variation in $\mathrm{pH}$ near fish cages versus time since the death of caged macrourids during (a) E1 and (b) E2. Circles: raw data collected every $5 \mathrm{~min}$; black line: $1 \mathrm{~h}$ running mean. Note the shorter time scale of E2. Phases of experiment indicated by notations (Pre-cage, Live, Scavenging, Consumed) and divided by vertical dashed lines. Precage: before the cage holding a live macrourid and octopus was placed in the camera view (E2); Live: when macrourid was observed swimming in the cage; Scavenging: started upon the death of the macrourid, Consumed: when large scavengers ceased visiting the area and the carcass had been mostly consumed

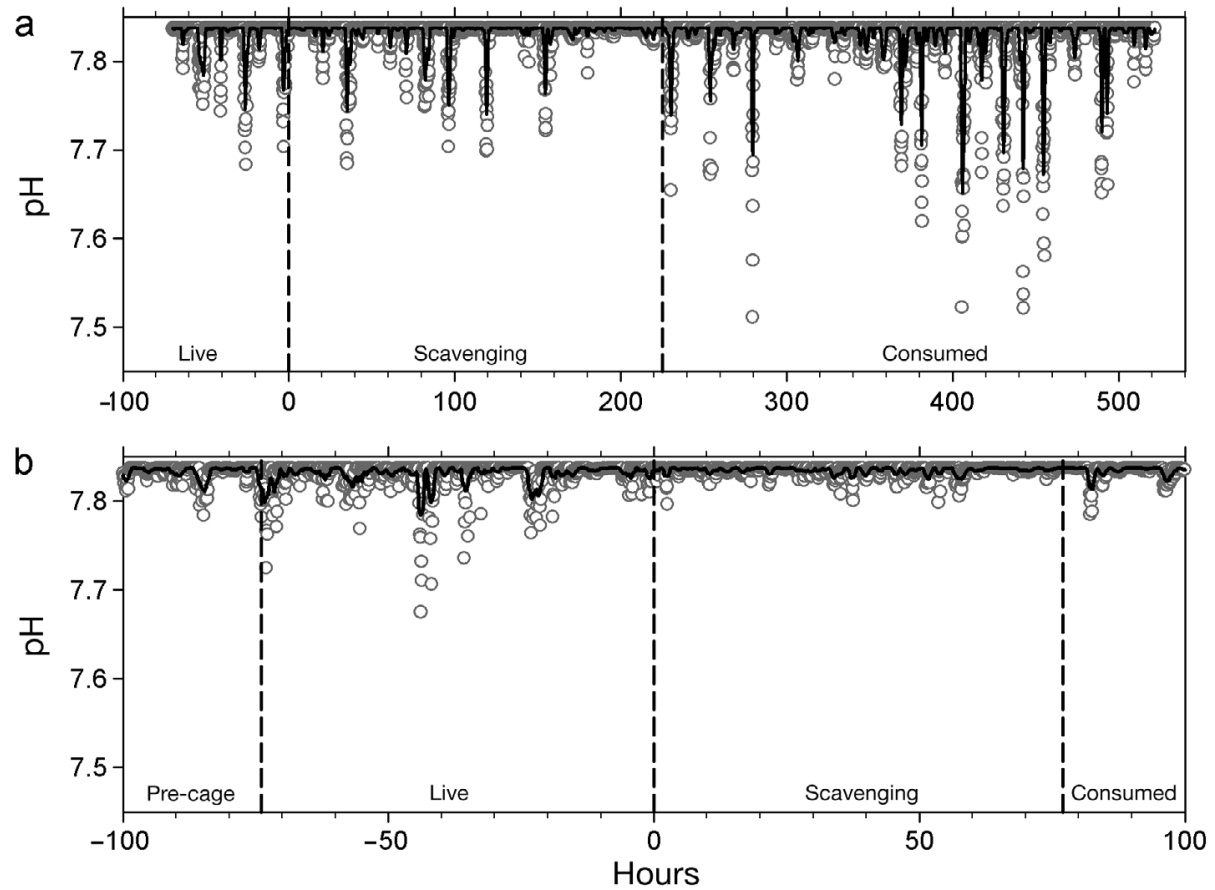

Because the odor plume and $\mathrm{CO}_{2}$-related acidification could have simultaneously affected scavenger behavior (e.g. Tamburri et al. 2000), the effects of $\mathrm{CO}_{2}$ alone can only be assessed prior to the death of the caged fish. If the analyses of $\mathrm{CO}_{2}$ effects are limited to the live period prior to any influence of an odor plume and when at least some significant variation in $\mathrm{pH}$ occurred in both experiments, there was still little evidence of a response to elevated $\mathrm{CO}_{2}$ levels by either scavengers or non-scavenger species. No significant correlations between $\mathrm{pH}$ and the abundance of any of the principal species observed in E1, E2, or E3 were detected. Nor did any animals display an adverse reaction to the acidic dissolution plume.

\section{Caged animal behavior}

The behavior of caged animals exposed to elevated $\mathrm{CO}_{2}$ levels varied among species. Coryphaenoides armatus typically swam near the top of cages, declining and dying within a few days in E1 and E2 (Fig. 5). One caged macrourid in E1 may have died after only $\sim 30 \mathrm{~h}$, based on its unchanging position on the bottom of the cage after this period (Fig. 5a). Pachycara bulbiceps rarely swam above the bottom of the cage (Fig. 5b), and was sedentary and generally motionless when visible during E1. Caged P. bulbiceps were not observed to consume $C$. armatus tissue during any of the $8 \mathrm{~s}$ video clips recorded in E1, even though it increased greatly in abundance outside the cage upon the macrourid's death. Caged Benthoctopus sp. in E2 moved frequently within the cage, particularly during the Live period (Fig. 5d), and appeared to attack its cell-mate 2 and $2.5 \mathrm{~d}$ after the start of the experiment. In these instances the octopus was in a feeding position with its arms around the macrourid (Fig. 3a). During the scavenging period, the Benthoctopus sp. apparently fed upon the carcass for a period of $\sim 34 \mathrm{~h}$, and then mostly clung to the top of the cage for the remainder of the time-lapse observations. Over this period the macrourids were skeletonized.

There is some indication that the caged Benthoctopus sp. and Coryphaenoides armatus avoided each other during E2. A Spearman's rank correlation coefficient calculated for the position indices of the 2 species during the live period was $-0.28(p<0.05)$. The correlation was positive (0.12), but non-significant, during the scavenging period, when the octopus was observed on the macrourid, apparently feeding, or at the top of the cage (Fig. 5).

\section{Abundance and behavior of free-ranging scavengers}

The abundance of scavengers and other benthos varied among phases and between experiments. Scavengers were observed during the live phase of E1 and E2, prior to the death of the caged macrourid, but were low in abundance compared to the scavenging phase. One exception to this pattern is the higher abundance of Coryphaenoides armatus at the beginning of E1, before its caged congener died (Fig. 6). Upon the death of the caged C. armatus in E1 and E2, 
a Coryphaenoides armatus (E1)

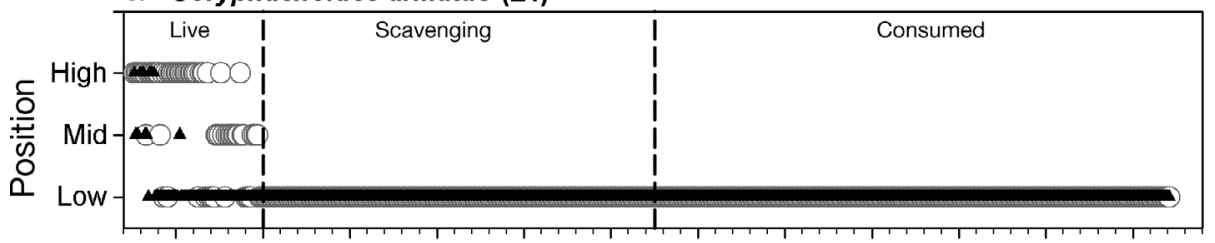

b Pachycara bulbiceps (E1)

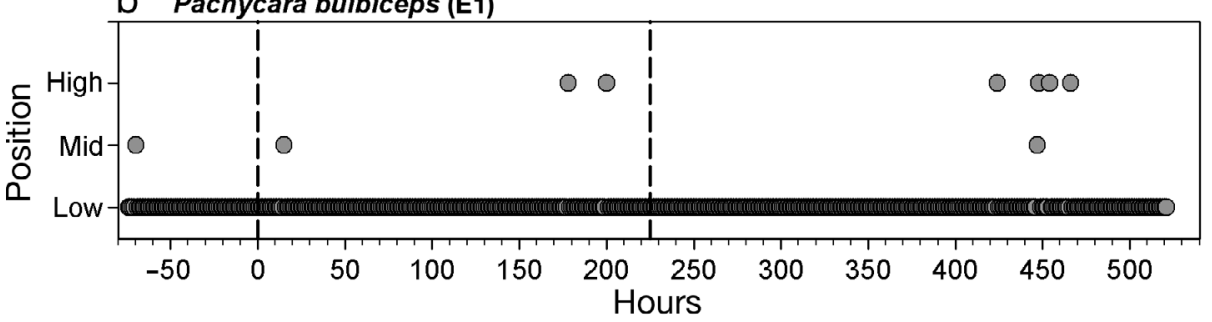

C Coryphaenoides armatus (E2)

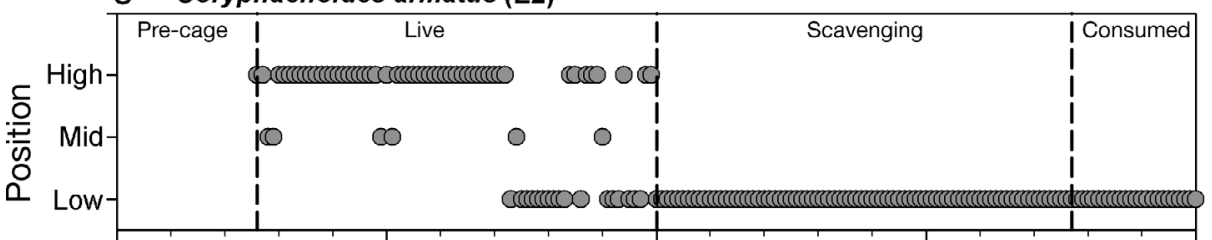

d Benthoctopus sp. (E2)

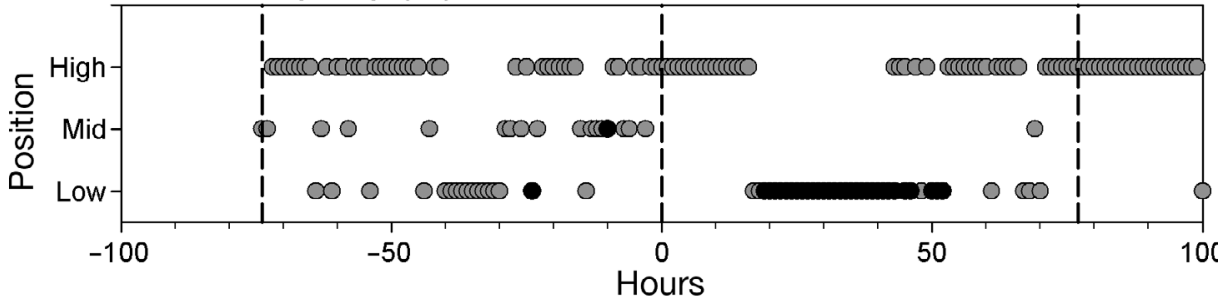

a Coryphaenoides armatus
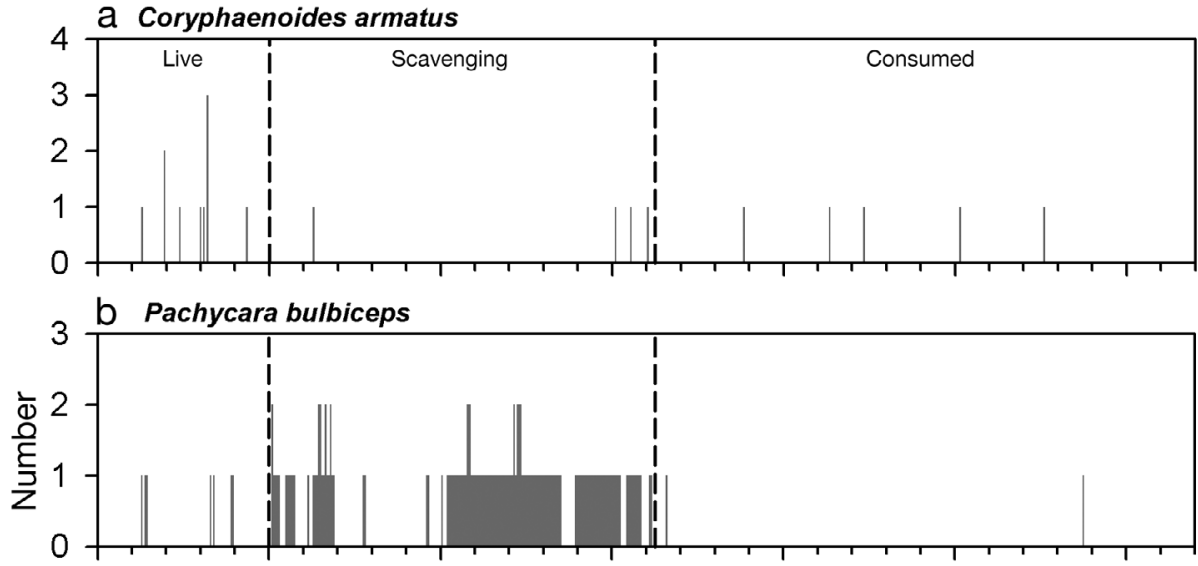

2 C Benthoctopus sp.

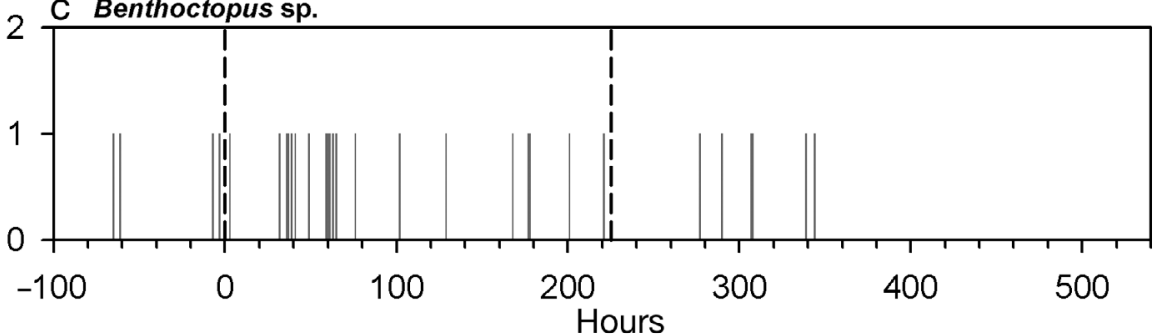

Fig. 5. Coryphaenoides armatus, Pachycara bulbiceps and Benthoctopus sp. Time series of scavenger activity inside cages. Low, mid, and high: the animal was observed in the bottom, middle, and upper third of the cage, respectively, for that image. Phases divided by dashed lines as in Fig. 4. E1: (a) $C$. armatus (Ind. $1=0$, Ind. $2=\boldsymbol{\Delta}$ ) and (b) P. bulbiceps $(\mathrm{n}=1)$. E2: (c) C. armatus ( $\mathrm{n}=1)$ and $(\mathrm{d})$ Benthoctopus sp. $(\mathrm{n}=1)$. Observations of apparent Benthoctopus attack on macrourid (live period) or apparent feeding on carcass by Benthoctopus (scavenging phase) (@). For $(\mathrm{b}, \mathrm{c}),(\mathrm{O})$ represents a single individual

Fig. 6. Coryphaenoides armatus, Pachycara bulbiceps and Benthoctopus sp. Abundance of scavengers during E1. Hours indicate the time from the death of the caged macrourids. Phases divided by dashed lines as in Fig. 4. (a) Number of $C$. armatus in images during the experiment. Note the lack of an increase in abundance following the death of the C. armatus individuals. (b) $P$. bulbiceps increased in frequency and abundance immediately following the death of the caged macrourids. (c) Benthoctopus sp. increased in frequency of occurrence for a period following the death of the macrourid 
the frequency of occurrence and abundance of the major scavengers increased, while visits by C. armatus to the cage decreased. During E2, scavengers, especially Pachycara bulbiceps and Bassozetus nasus (Ophidiidae), aggregated near the cage a few hours before the caged macrourid's death, and then increased greatly following its demise (Fig. 7). Benthoctopus sp. and a small unidentified zoarcid species (possibly juvenile $P$. bulbiceps) also increased in response to the death of the macrourid, but were slower to arrive or increase in frequency near the cages, and reached peak abundances only after the number of $P$. bulbiceps and $B$. nasus waned. The strong response of scavengers is also evident by changes in the percentage of images with scavengers among periods (Table 2). Scavenging fishes were not able to feed on the macrourid carcasses because of their position within cages. Benthoctopus sp., however, could reach into the cage and pull the carcass to the cage margin for feeding. All scavengers were rare during the Consumed phase.
Correlation analyses used to assess interactions among scavengers suggested that Benthoctopus sp. and the unidentified small zoarcid may have avoided interactions with Pachycara bulbiceps and B. nasus. Spearman's rank correlation coefficients for the abundance of $P$. bulbiceps or B. nasus and either Benthoctopus sp. or the unidentified zoarcid were not significant for the Live period. For the Scavenging period of E2, however, the abundance of the small zoarcid was negatively correlated to both $P$. bulbiceps $(\mathrm{R}=-0.20, \mathrm{p}<0.05)$ and B. nasus $(\mathrm{R}=-0.20$, $\mathrm{p}<0.05)$. In addition, the abundances of Benthoctopus sp. and $P$. bulbiceps were negatively correlated $(\mathrm{R}=$ $-0.29, \mathrm{p}<0.05$ ) during the Scavenging period.

A surprising result of the scavenger observations was the lack of response by macrourids in the vicinity to the death of the caged macrourids. Coryphaenoides armatus did not increase in abundance or frequency of occurrence following the death of their caged conspecifics (Figs. 6 \& 7). Instead, C. armatus decreased in abundance and frequency upon the death of the caged macrourid during E1.
Fig. 7. Abundance of visiting scavengers during E2. Hours indicate the time from the death of the caged macrourid. Phases divided by dashed lines as in Fig. 4. (a) Coryphaenoides armatus, (b) Pachycara bulbiceps, (c) Bassozetus nasus, (d) Benthoctopus sp., and (e) unknown zoarcid species. Note the shift in activity and visitation following the macrourid's demise
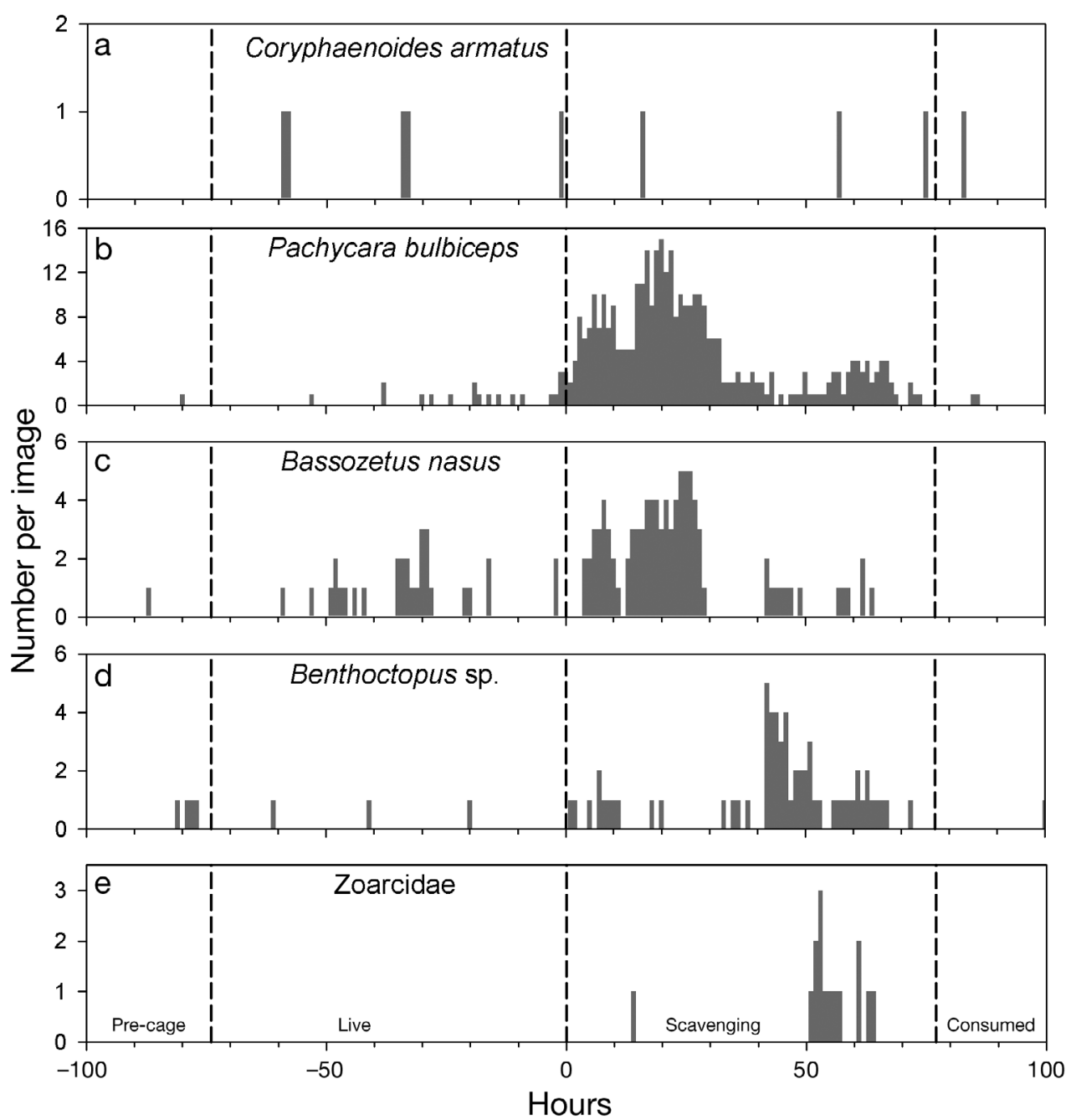
Table 2. Percentage of images in E2 with various deep-sea species, by experimental phase. Pre-cage: the phase prior to placement of the cage in the view of the camera. Live: the phase when the macrourid was observed swimming or moving within the cage. Scavenging: the phase after its death, when scavenging species were present in high abundances. Consumed: the phase after scavenger abundances dropped to background levels and the carcass appeared to be skeletonized. Note the increase in percentage observations for the principal scavengers (Pachycara bulbiceps, Bassozetus nasus, Benthoctopus sp., and the small unidentified zoarcid) during the scavenging period. Unident. = unidentified

\begin{tabular}{|llcccc|}
\hline Species & Group & Pre-cage & Live & Scavenging & Consumed \\
\hline Pachycara bulbiceps & Zoarcidae & 4.2 & 19.2 & 92.2 & 8.3 \\
Bassozetus nasus & Ophidiidae & 4.2 & 27.4 & 48.1 & 0.0 \\
Benthoctopus sp. & Octopodidae & 16.7 & 4.1 & 50.6 & 4.2 \\
Small unident. sp. & Zoarcidae & 0.0 & 0.0 & 6.8 & 0.0 \\
Coryphaenoides armatus & Macrouridae & 0.0 & 74.0 & 100.0 & 9.2 \\
Aporocidaris milleri & Cidaridae & 87.5 & 12.3 & 81.8 & 7.8 \\
Mohnia vernalis & Buccinidae & 91.7 & 84.9 & 0.0 & 100.0 \\
Unident. sp. & Ophiuroidea & 100.0 & 0.0 & 0.0 & 0.0 \\
Unident. sp. & Munnopsidae & 12.5 & 1.4 & 1.3 & 0.0 \\
Cystechinus loveni & Urechinidae & 100.0 & 1.4 & 2.6 & 4.2 \\
Amperima robusta & Elpididae & 20.8 & 1.4 & & 25.0 \\
Unident. sp. & Pycnogonida & 0.0 & & & \\
\hline
\end{tabular}

Common megafaunal invertebrates did not exhibit a strong response to the death of the macrourids. A few individuals of abyssal echinoids Aporocidaris milleri (Cidaridae), Cystechinus loveni (Urechinidae), and Ophiuroidea were observed in the camera view during all phases of E2, but did not change greatly in abundance between periods (Fig. 8). One A. milleri individual crawled slowly to the cage, but wandered out of view. Nor did C. loveni exhibit a response to the macrourid carcass. The buccinid gastropod Mohnia vernalis was observed occasionally. At least $1 M$. vernalis was observed in successive images to crawl to the cage and onto the macrourid carcass. It is possible that others were present, but were obscured from view by the cage or other scavengers. Very low numbers of scavengers were observed during E3, which had no odor plume from caged fish, dead or alive. Coryphaenoides armatus was observed 5 times in 100
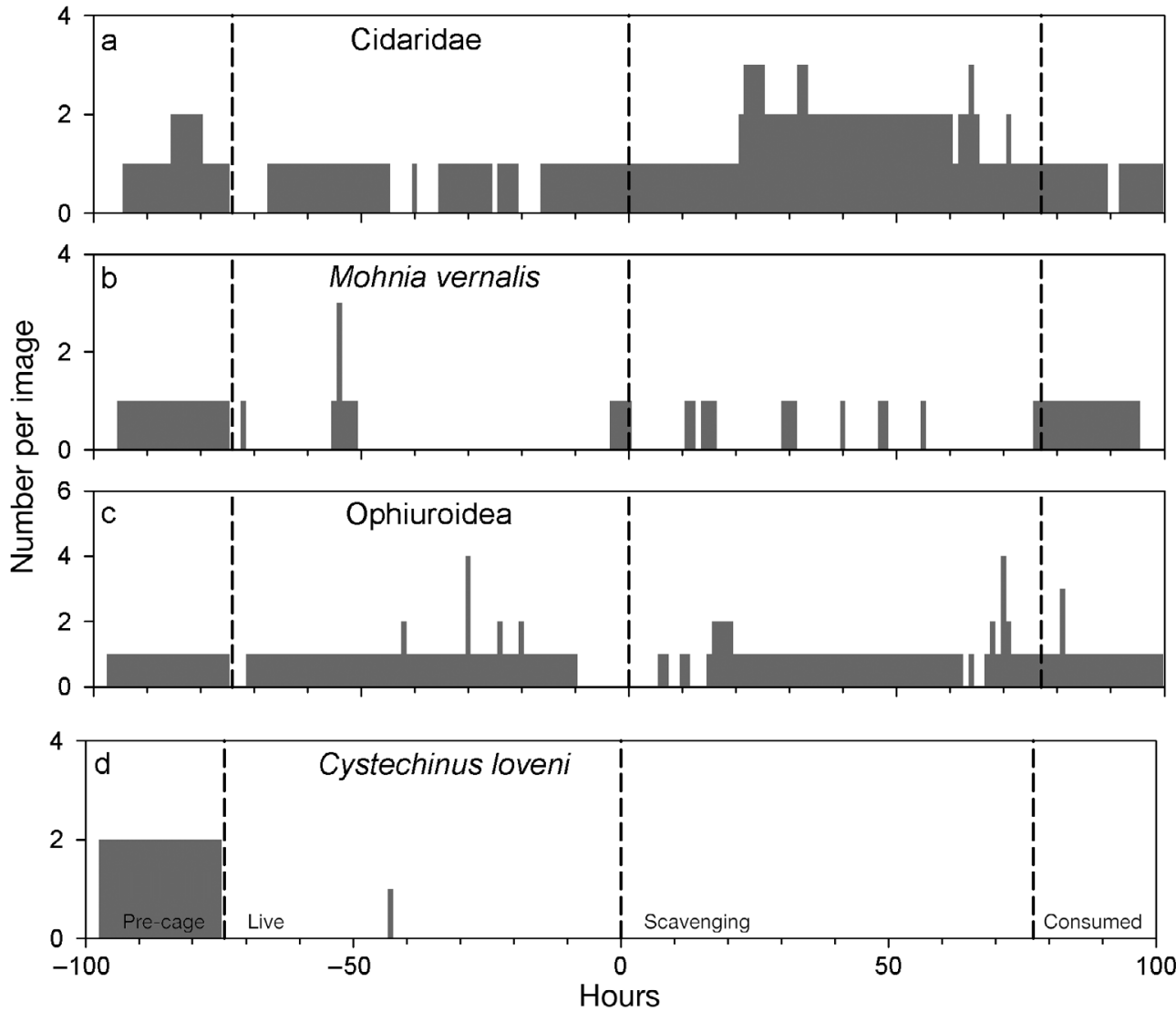

Fig. 8. Abundance of minor species in time-lapse images before and following the death of the caged macrourid during the 2003 experiment. Phases divided by dashed lines as in Fig. 4. (a) Cidarid urchins, (b) Mohnia vernalis (Gastropoda), (c) Ophiuroidea, and (d) Cystechinus loveni (echinoid) 
images taken over $\sim 200 \mathrm{~h}$. Munnopsid isopods were the most abundant invertebrate, with 3 to 6 ind. visible in nearly all images. Benthic megafauna, including ophiuroids, holothurians, and gastropods ( $M$. vernalis) were observed commonly as single individuals present in successive images as they wandered through the area, similar to observations in E2.

\section{DISCUSSION}

\section{Effects of ocean acidification on abyssal scavengers}

The potential effects of elevated ocean carbon dioxide levels include reduced calcification, respiratory stress, acid-base imbalance, metabolic depression, and potentially $\mathrm{CO}_{2}$-induced torpor (Pörtner et al. 2004 b, Raven et al. 2005). Although knowledge of the effects of high $\mathrm{CO}_{2}$ tensions on deep-sea fishes is poor, tolerance is known to vary among species, perhaps related to their ability to control osmolytes (Ishimatsu \& Kita 1999, Ishimatsu et al. 2005). We have observed Coryphaenoides armatus to swim in very close proximity to pools of liquid $\mathrm{CO}_{2}$, but their tolerance to longterm ocean acidification is unknown. $\mathrm{CO}_{2}$-related stress may have contributed to the death of the caged macrourids positioned near $\mathrm{CO}_{2}$ pools $(\mathrm{n}=3$ in these experiments), but this could not be evaluated, since all caged macrourids died, including those within cages at control sites with no $\mathrm{CO}_{2}$ stress $(\mathrm{n}=3)$. Unfortunately, it appears that mortality associated with cage-related stress was sufficiently high that all study animals died, precluding a comparison of survival rates for macrourids exposed to hypercapnic and normocapnic waters.

In contrast to Coryphaenoides armatus, all caged individuals of the zoarcid Pachycara bulbiceps and the octopus Benthoctopus sp. survived exposure at $\mathrm{CO}_{2}$ treatment sites. $P$. bulbiceps was potentially exposed to the most severe stress due to its position on the seabed and the slightly negative buoyancy of the $\mathrm{CO}_{2}$ dissolution plume. In addition, $\mathrm{pH}$ perturbations were likely larger during E1 for $P$. bulbiceps held in cages $0.5 \mathrm{~m}$ from the $\mathrm{CO}_{2}$ pool. The $\mathrm{pH}$ sensors failed at this distance, but data from other experiments indicate that $\mathrm{pH}$ likely dropped by $1 \mathrm{U}$ or more. Thus, $P$. bulbiceps is probably tolerant of more severe bouts of elevated $\mathrm{CO}_{2}$ levels than indicated by the $\mathrm{pH}$ data presented here, which were collected $5 \mathrm{~m}$ from $\mathrm{CO}_{2}$ pools. Overall, we placed $16 P$. bulbiceps at distances from $\mathrm{CO}_{2}$ pools of 0.5 to $5 \mathrm{~m}$, where $\mathrm{pH}$ perturbations were episodic, but ranged from near -0.1 to $>-1.0 \mathrm{U}$, and 6 ind. at control sites with no $\mathrm{CO}_{2}$. All $P$. bulbiceps survived both month-long experiments. This confirms that the impaired physiological performance observed in cellular preparations of its shallower congener, Pachycara brachycephalum, during in vitro studies with $\mathrm{pH}$ perturbations near -0.6 U (Langenbuch \& Pörtner 2003) does not characterize the sensitivity of the intact organism. Deep-sea cephalopods, including Benthoctopus sp., are known to be highly sensitive to even small changes in $\mathrm{pH}$ (Pörtner et al. 1998, Seibel \& Walsh 2003). Thus, it is somewhat surprising that the caged Benthoctopus sp., as well as 2 others that have been in cages near $\mathrm{CO}_{2}$ pools, survived the monthlong period within the cage. Further studies are required to evaluate the metabolic costs of $\mathrm{CO}_{2}$ tolerance and long-term consequences of increasing ocean acidification for deep-sea animals.

\section{Mortality of caged macrourids}

Death of macrourid fishes after 2 to $3 \mathrm{~d}$ within cages on the abyssal seabed was an unexpected, yet serendipitous event, providing an opportunity to observe the response of the abyssal scavenger assemblage, including conspecifics and congeners, to the odor plume following the caged macrourids' deaths. Several factors may have contributed to their death, including the stress of confinement inside cages, increased exposure and interactions with potential predators (e.g. Benthoctopus sp., lysianassid amphipods), and the exposure to the $\mathrm{CO}_{2}$-rich dissolution plume. Macrourids use a sensory barbel for gustation and mechanoreception while swimming in a somewhat head-down position (Bailey et al. 2007). This typical swimming behavior, along with their lack of experience with walls of any sort, may compromise their ability to detect the gaps in the cage mesh, leading to injury and death. Although each of these factors may have contributed, high mortality rates of caged macrourids have been observed by other investigators (Bailey et al. 2002).

\section{Response of scavengers to the macrourid odor plume}

The most striking result of the time-lapse observations was the indifference or possible avoidance of the odor plume by macrourids common at the study sites (mainly Coryphaenoides armatus). C. armatus was observed frequently at the study sites prior to the experiment and is a common scavenger at these depths.

Baited cameras in some areas and at some depths have not been visited heavily by macrourids. Macrourids were abundant in images at $1900 \mathrm{~m}$, but were not observed at $4040 \mathrm{~m}$ over shark carcasses deployed in the Arabian Sea (Witte 1999). Results of video surveys at the sites largely mimicked those from the baited camera, with no macrourids observed at $4040 \mathrm{~m}$ depth. Thus, the local scavenger species pool did not include 
macrourids at Witte's abyssal site. In contrast, Coryphaenoides armatus is one of the most abundant benthopelagic fishes at our study site, based on non-quantitative observations during ROV dive operations, and was readily captured in cages baited with mackerel.

At least 4 hypotheses may explain the avoidance or low response of Coryphaenoides armatus or other macrourids to the death of the caged $C$. armatus. First, grenadiers may have avoided the area due to the presence of the $\mathrm{CO}_{2}$-rich dissolution plume. This explanation is not supported by the combination of $\mathrm{pH}$ and image data and ROV observations during the experiments. Macrourids were observed frequently during the initiation of the experiment and were the only scavenging fish to be observed near the $\mathrm{CO}_{2}$ in E3, frequently swimming near $\mathrm{CO}_{2}$ pools during ROV operations (J. Barry pers. obs.). Observations of the indifference exhibited by bathyal scavengers exposed to $\mathrm{CO}_{2}$-rich seawater and odor plumes (Tamburri et al. 2000) also does not support this hypothesis. Although the $\mathrm{CO}_{2}$-rich dissolution plume may have contributed to the death of the caged macrourid, this is not possible to evaluate since caged macrourids ( 2 in E1 and 1 in E2) positioned in control areas 50 to $100 \mathrm{~m}$ from $\mathrm{CO}_{2}$ pools (where $\mathrm{pH}$ perturbations were undetectable) also died.

Second, macrourids may remain near food falls only in cases where access to the carcass is possible. The location of the macrourid carcass within the fish trap precluded feeding by macrourids visiting the cage. They may reduce risk of injury or death by leaving a site once they determine that feeding is difficult or impossible, regardless of the odor plume. This hypothesis is not supported by the observation of equal or fewer visits during the Live than Scavenging period in E2. Because it would require some period of time to assess feeding potential, an odor plume, if attractive, should result in higher attendance near the bait (and in images). The observed decrease or unchanged abundance of macrourids during the scavenging period tends to refute this hypothesis. The higher frequency of visits during the Live phase of E1 was likely related to the presence of some original bait remaining in the cage, which was not removed at the beginning of the experiment as in E2.

Third, the nutritional composition of the bait is likely to affect both the size and character of the odor plume, thereby influencing the response of the scavenger guild. It is possible that the odor plume from macrourids as bait is both smaller and less appealing to scavengers due to its lower lipid and protein concentrations, compared to those of shallow-water fishes or cetaceans. Depth-related trends in the composition of fish tissues have been reported by several investigators, but remain somewhat controversial. Bailey \&
Robison (1986) note a decrease in lipid, caloric, and protein content among fishes with depth. Closer examination of depth-related patterns among feeding type and position (i.e. benthic or benthopelagic) of demersal fishes revealed that the depth-related trends are coupled to mobility rather than food availability (Drazen 2007), with major changes in nutritional composition restricted largely to shallower, sunlit waters. Although the protein content of $C$. armatus tissue $(\sim 15.6 \%)$ is high compared to that of most demersal fishes at bathyal and abyssal depths (Drazen 2007), it is lower than that found in fishes such as mackerel $(\sim 18 \%$; Hardy \& Keay 1972) or cetacean tissues (4 to $38 \%$; Kannan et al. 1996). In addition, although the lipid-rich liver of $C$. armatus increases its total energy density, the lipid content of shallow-water species is far higher (e.g. mackerel tissue lipid 15\% [Hardy \& Keay 1972], cetacean blubber lipid $\sim 60 \%$ [Aguilar \& Borrel 1990]). Thus, the caloric density available to scavengers from C. armatus is clearly lower than that in studies using shallow-water species as bait, and may have contributed to the pattern of macrourid scavenging observed in the present study and in the study by Lampitt et al. (1983). On the contrary, however, other typical scavengers (liparids, ophidiids, octopodids, zoarcids, lysianassids) appeared at baited cameras rapidly and abundantly in these studies, which does not support the hypothesis that the odor plume was deficient in some ways that would attract demersal scavengers.

Fourth, macrourids may either be unresponsive to or actively avoid the odor plume of conspecific or congener species. This could explain the reduced frequency of Coryphaenoides armatus observed during the Scavenging phase of E1 and the relatively constant number of macrourids observed throughout E2. We could find only 1 study (Lampitt et al. 1983) that used a macrourid (C. armutus) as bait for traps or camera studies of deep-sea scavengers. Their trap and camera deployments at the Porcupine Seabight in the North Atlantic attracted mainly lysianassid amphipods and the liparid fish Paraliparis bathybius. C. armatus was captured in the trap and was observed at the baited camera station, but in very low numbers. In contrast, camera systems baited with mackerel (Smith et al. 1997) or small cetaceans (Jones et al. 1998, Kemp et al. 2006) and deployed in the same area (23 to $315 \mathrm{~km}$ away) reported $C$. armatus as the overwhelmingly dominant scavenger. Collins et al. (1999) used bathyal toothfish Dissostichus eleginoides and squid as bait in camera systems deployed from 900 to $1750 \mathrm{~m}$, in which toothfish visited the site, but did not consume either bait type. Other scavengers (hagfish, Myxinidae; stone crabs, Lithodidae; blue hake, Moridae; and amphipods) were much more abundant and consumed the 
bait. Avoidance of conspecific odor plumes could confer a fitness advantage if it leads to higher survival, in spite of lost feeding opportunities at potentially dangerous sites. It is also possible that chemical releases from stressed, live animals, such as those held in cages during these experiments, could deter congeners from the area. Results from studies in shallow water, however, suggest that odors from conspecifics often deter attendance near bait (Moore \& Howarth 1996 and references therein).

Non-macrourid benthic and benthopelagic megafauna were common in time-lapse images and increased greatly in abundance immediately after the death of the caged macrourids. Like grenadiers, zoarcids and ophidiids are common scavengers at deep-sea food falls in both the Pacific and Atlantic Ocean basins (Wilson \& Smith 1984, Jones et al. 1998, Premke et al. 2003, Kemp et al. 2006). Pachycara bulbiceps is common near our study sites, based on ROV observations during the initiation of the experiments. It was observed frequently prior to the initiation of the experiments, and responded strongly to the death of Coryphaenoides armatus. Bassozetus nasus was observed several times during the Live period, but its response to the carcass lagged behind that of $P$. bulbiceps by several hours. It is possible that the odor plume was most intense near the seabed, where P. bulbiceps, a benthic species, would be more likely to encounter it than a benthopelagic species.

The pattern of visitation for Pachycara bulbiceps and Bassozetus nasus during the Scavenging period of E2 was somewhat contrary to expectations. The ophidiid B. nasus is a benthopelagic fish that typically swims or hovers above the seabed. The zoarcid $P$. bulbiceps is benthic, and was usually motionless on the seabed. Assuming that it is principally a 'sit and wait' forager (Wilson \& Smith 1984), due to its sedentary nature, its behavior near the cage would be expected to be similar to Bailey \& Priede's (2002) 'sit and wait' model (their Fig. 4). In their model, abundance rises rapidly to a peak, then drops abruptly following consumption of the bait. Instead, the pattern of visits for P. bulbiceps (Fig. 7) was much more similar to a crosscurrent foraging model (Priede et al. 1990, Bailey \& Priede 2002), with a rapid rise in abundance and a rapid, but not precipitous, drop in abundance at the end of the scavenging period. Nor did B. nasus exhibit a pattern of abundance at the cage that was expected for its presumed foraging mode. Its benthopelagic mode suggests a cross-current foraging strategy, but its pattern of abundance (Fig. 7) more closely fits a 'sit and wait' model. Another consideration is the role of caged food falls in the area of the experiment, which could influence the pattern of scavenger visits at the camera location.
Changes in the relative abundance of scavengers suggest a successional sequence of exploitation, potentially driven by species-specific responses to the odor plume, interspecific interactions, or both. Successional changes in scavenger attendance at baited cameras have been detected for larger food falls, but rarely for small bait parcels consumed within hours. Owing to the long persistence and the heterogeneous resources available at whale falls, there is a well-documented succession of animals exploiting these sites (Smith et al. 2003). Smaller nekton falls can also have large effects on benthic communities, both from their role in carbon input as well as the physical disturbance to the seabed during active scavenging of the carcass (Smith 1985, 1986). Successional changes at food falls may also be motivated by predator avoidance or increases in predator abundance near aggregated prey (Smith 1985). Macrourids and liparids are known to consume lysianassid amphipods at food falls (Lampitt et al. 1983, Jones et al. 1998). Amphipods may be responsible for much of the consumption of some food falls, and fall prey to macrourids, liparids, zoarcids, or other predators. Typically, only large macrourids are photographed at bait (King et al. 2006), and only large specimens have carrion in their stomachs (Drazen et al. 2001), suggesting that small individuals are unable to compete for resources at food falls or actively avoid them due to predation risk. Ontogenetic increases in the size of the olfactory lobe of Coryphaenoides armatus indicate a shift from visual to olfactory cues (Wagner 2003), which may also influence the reduced response of small macrourids to odor plumes. By 4 to $9 \mathrm{~d}$ following their death, the macrourid carcasses, though visible in images, appeared largely consumed except for the skin, and were no longer attended by megafaunal scavengers. It is likely that smaller species, including lysianassids, ophiuroids, and molluscs, were still actively consuming the carcass, but were not visible in images. The odor plume appeared to have diminished to the point that no additional scavengers were attracted.

The Scavenging phase for macrourid carcasses in this study was considerably longer than has been observed in various other studies when a single mackerel was used for bait. We assume this is due to the limited access by megafaunal scavengers. The Benthoctopus sp. inside the cage had direct access to the macrourid carcass in E1 and appeared to feed upon it during the scavenging period, apparently moving the carcass within the cage. Other Benthoctopus sp. visiting the cage were observed to reach into the cage, apparently pulling the carcass toward them so that they may feed on it. Amphipods, sampled poorly by this study, had the greatest access to the carcass, and very likely consumed a significant portion of the carcass, as well as being fed upon by other scavengers. 
Although our observations of scavenger responses to the macrourid odor plume support the hypothesis of aversion to odors from injured or dead conspecifics, our experiments were not designed to evaluate this hypothesis. Our test of this hypothesis lacks adequate controls, and the effects of odor plumes are confounded with those caused by the $\mathrm{CO}_{2}$-rich dissolution plume from nearby $\mathrm{CO}_{2}$ pools. Future studies of scavenger behavior should include observations of scavenger responses at several sites with and without macrourid bait, and in the absence of $\mathrm{CO}_{2}$-laden waters. Integration of our understanding of factors influencing scavenger behavior with information concerning the impacts of exposure to $\mathrm{CO}_{2}$-enriched waters will increase our abilities to forecast changes in deep-sea ecosystems under future changes in ocean chemistry.

Acknowledgements. This project was supported by the Monterey Bay Aquarium Research Institute (Project 200002), the Ocean Carbon Sequestration Research Program, Biological and Environmental Research (BER), US Department of Energy (Award Nos. DE-FG03-01DF63065 \& DE-FG02-04ER63721), and the National Energy Technology Laboratory (NETL), US Department of Energy (Award No. DE-FC26-00NT40929). We are particularly grateful to P. Brewer, E. Peltzer, and P. Walz for their assistance in the field studies and the carbon dioxide delivery system, to K. Sullivan for help with the timelapse camera systems, and to the outstanding support from the crews of the RV 'Western Flyer' and the ROV 'Tiburon'. Reviewers of the manuscript and the guest editor provided very valuable comments that improved the content and readability of the manuscript.

\section{LITERATURE CITED}

Aguilar A, Borrel A (1990) Patterns of lipid content and stratification in the blubber of fin whales (Balaenoptera physalus). J Mamm 71:544-554

Armstrong JD, Priede IG, Smith KLJ (1991) Temporal change in foraging behaviour of the fish Coryphaenoides (Nematonurus) yaquinae in the central North Pacific. Mar Ecol Prog Ser 76:195-199

Bailey DM, Priede IG (2002) Predicting fish behaviour in response to abyssal food falls. Mar Biol 141(5):831-840

Bailey TG, Robison BH (1986) Food availability as a selective factor on the chemical compositions of midwater fishes in the eastern North Pacific. Mar Biol 91(1):131-141

Bailey DM, Jamieson AJ, Bagley PM, Collins MA, Priede IG (2002) Measurement of in situ oxygen consumption of deep-sea fish using an autonomous lander vehicle. DeepSea Res 49(8):1519-1529

Bailey DM, Wagner HJ, Jamieson AJ, Ross MF, Priede IG (2007) A taste of the deep-sea: the roles of gustatory and tactile searching behaviour in the grenadier fish Coryphaenoides armatus. Deep-Sea Res 54(1):99-108

Barry JP, Buck KR, Lovera CF, Kuhnz L and others (2004) Effects of direct ocean $\mathrm{CO}_{2}$ injection on deep-sea meiofauna. J Oceanogr 60:759-766

Barry JP, Buck KR, Lovera C, Kuhnz C, Whaling PJ (2005) Utility of deep-sea $\mathrm{CO}_{2}$ release experiments in understanding the biology of a high $\mathrm{CO}_{2}$ ocean: effects of hypercapnia on deep-sea meiofauna. J Geophys Res C C09S12:1-18
Caldiera K, Wickett ME (2003) Oceanography: Anthropogenic carbon and ocean $\mathrm{pH}$. Nature 35:117-126

Collins MA, Yau C, Nolan CP, Bagley PM, Priede IG (1999) Behavioural observations on the scavenging fauna of the Patagonian slope. J Mar Biol Assoc UK 79:963-970

Drazen JC (2007) Depth related trends in proximate composition of demersal fishes in the eastern North Pacific. DeepSea Res 54(2):203-219

Drazen JC, Buckley TW, Hoff GR (2001) The feeding habits of slope dwelling macrourid fishes in the eastern North Pacific. Deep-Sea Res 48:909-935

Hardy R, Keay JN (1972) Seasonal variations in the chemical composition of Cornish mackerel, Scomber scombrus (L), with detailed reference to the lipids. Int J Food Sci Technol 7:125-137

Isaacs JD, Schwartzlose RA (1975) Active animals of the deep-sea floor. Sci Am 233:85-91

Ishimatsu A, Kita J (1999) Effects of environmental hypercapnia on fish. Jpn J Ichthyol 46(1):1-13

Ishimatsu A, Hayashi M, Lee KS, Kikkawa T, Kita J (2005) Physiological effects on fishes in a high- $\mathrm{CO}_{2}$ world. $\mathrm{J}$ Geophys Res C Oceans C09S09:1-8

Jones EG, Collins MA, Bagley PM, Addison S, Priede IG (1998) The fate of cetacean carcasses in the deep sea: observations on consumption rates and succession of scavenging species in the abyssal North-East Atlantic Ocean. Proc R Soc Lond Ser B 265:1119-1127

Kannan K, Corsolini S, Focardi S, Tanabe S, Tatsukawa R (1996) Accumulation pattern of butyltin compounds in dolphin, tuna, and shark collected from Italian coastal waters. Arch Environ Contam Toxicol 31:19-23

Kemp KM, Jamieson AJ, Bagley PM, McGrath H, Bailey DM, Collins MA, Priede IG (2006) Consumption of large bathyal food fall, a six month study in the NE Atlantic. Mar Ecol Prog Ser 310:65-76

King NJ, Bagley PM, Priede IG (2006) Depth zonation and latitudinal distribution of deep-sea scavenging demersal fishes of the Mid-Atlantic Ridge, 42 to 53 N. Mar Ecol Prog Ser 319:263-274

Lampitt RS, Merrett NR, Thurston MH (1983) Inter-relations of necrophagous amphipods, a fish predator, and tidal currents in the deep-sea. Mar Biol 74:73-78

Langenbuch M, Pörtner HO (2003) Energy budget of hepatocytes from Antarctic fish (Pachycara brachycephalum and Lepidonotothen kempi) as a function of ambient $\mathrm{CO}_{2}$ : $\mathrm{pH}-$ dependent limitations of cellular protein biosynthesis? J Exp Biol 206:3895-3903

McKillup SC, McKillup RV (1992) Inhibition of feeding in response to crushed conspecifics by the pebble crab Philyra laevis (Bell). J Exp Mar Biol Ecol 161(1):33-43

McKillup SC, McKillup RV (1994) The decision to feed by a scavenger in relation to the risks of predation and starvation. Oecologia 97(1):41-48

Moore PG, Howarth J (1996) Foraging by marine scavengers: effects of relatedness, bait damage and hunger. J Sea Res 36:267-273

Moore PG, Wong YM (1995) Orchomene nanus (Kroyer) (Amphipoda: Lysianassoidea), a selective scavenger of dead crabs: feeding preferences in the field. J Exp Mar Biol Ecol 192:35-45

Orr JC, Fabry VJ, Aumont O, Bopp L and others (2005) Anthropogenic ocean acidification over the twenty-first century and its impact on calcifying organisms. Nature 437:681-686

Pörtner HO, Hardewig I, Sartoris FJ, Van Dijk PLM (1998) Energetic aspects of cold adaptation: Critical temperatures in metabolic, ionic and acid-base regulation. In: 
Pörtner HO, Playle RC (eds) Cold ocean physiology. Cambridge University Press, Cambridge, p 88-120

Pörtner HO, Langenbuch M, Michaelidis B (2004a) Effects of $\mathrm{CO}_{2}$ on marine animals: interactions with temperature and hypoxia regimes. J Geophys Res C09S10:1-15

Pörtner HO, Langenbuch M, Reipschlager A (2004b) Biological impact of elevated ocean $\mathrm{CO}_{2}$ concentrations: Lessons from animal physiology and earth history. J Oceanogr 60:705-718

Premke K, Muyakshin S, Klages M, Wegner J (2003) Evidence for long-range chemoreceptive tracking of food odour in deep-sea scavengers by scanning sonar data. J Exp Mar Biol Ecol 285:283-294

Priede IG, Bagley PM (2000) In situ studies on deep-sea demersal fishes using autonomous unmanned lander platforms. Oceanogr Mar Biol Annu Rev 38:357-392

Priede IG, Smith KLJ, Armstrong JD (1990) Foraging behavior of abyssal grenadier fish inferences from acoustic tagging and tracking in the North Pacific Ocean. Deep-Sea Res I 37:81-102

Priede IG, Bagley PM, Armstrong JD, Smith KLJ, Merrett NR (1991) Direct measurement of active dispersal of food-falls by deep-sea demersal fishes. Nature 351:647-649

Priede IG, Bagley PM, Smith KL Jr (1994) Seasonal change in activity of abyssal demersal scavenging grenadiers Coryphaenoides (Nematonurus) armatus in the eastern North Pacific Ocean. Limnol Oceanogr 39:279-285

Raven JA, Caldeira K, Elderfield H, Hoegh-Guldberg $\mathrm{O}$ and others (2005) Ocean acidification due to increasing atmospheric carbon dioxide. The Royal Society, London

Rowe GT, Sibuet M, Vangriesheim A (1986) Domains of occupation of abyssal scavengers inferred from baited cameras and traps on the Demerara Abyssal Plain, North Atlantic Ocean. Deep-Sea Res 33:501-522

Sabine CL, Feely RA, Gruber N, Key RM and others (2004) The oceanic sink for anthropogenic $\mathrm{CO}_{2}$. Science 305:367-371

Seibel BA, Walsh PJ (2001) Potential impacts of $\mathrm{CO}_{2}$ injection on deep-sea biota. Science 294:319-320

Seibel B, Walsh P (2003) Biological impacts of deep-sea

Editorial responsibility: Howard Browman (Associate Editorin-Chief), Storebø, Norway carbon dioxide injection inferred from indices of physiological performance. J Exp Biol 206:641-650

Shirayama Y (1998) Biodiversity and biological impact of ocean disposal of carbon dioxide. Waste Manage 17: 381-384

Smith A, Priede IG, Bagley PM, Addison SW (1997) Interception and dispersal of artificial food falls by scavenging fishes in the abyssal Northeast Atlantic: early-season observations prior to annual deposition of phytodetritus. Mar Biol 128:329-336

Smith CR (1985) Food for the deep sea: utilization, dispersal, and flux of nekton falls at the Santa Catalina Basin floor. Deep-Sea Res I 32(4):417-442

Smith CR (1986) Nekton falls, low-intensity disturbance and community structure of infaunal benthos in the deep sea. J Mar Res 44:567-600

Smith CR, Baco AR, Gibson RN, Atkinson RJA (2003) Ecology of whale falls at the deep-sea floor. Oceanogr Mar Biol Annu Rev 41:311-354

Tamburri MN, Peltzer ET, Friederich GE, Aya I, Yamane K, Brewer PG (2000) A field study of the effects of $\mathrm{CO}_{2}$ ocean disposal on mobile deep-sea animals. Mar Chem 72:2-4

Thistle D, Carman KR, Sedlacek L, Brewer PG, Fleeger JW, Barry JP (2005) Deep-ocean, sediment-dwelling animals are sensitive to sequestered carbon dioxide. Mar Ecol Prog Ser 289:1-4

Wagner HJ (2003) Volumetric analysis of brain areas indicates a shift in sensory orientation during development in the deep-sea grenadier Coryphaenoides armatus. Mar Biol 142:791-797

Wilson RR Jr, Smith KL Jr (1984) Effect of near-bottom currents on detection of bait by the abyssal grenadier fishes Coryphaenoides spp., recorded in situ with a video camera on a free vehicle. Mar Biol 84:83-91

Witte U (1999) Consumption of large carcasses by scavenger assemblages in the deep Arabian Sea: observations by baited camera. Mar Ecol Prog Ser 183:139-147

Wolff T (1976) Utilization of plant remains, mainly seagrass, by deep-sea animals. In: Proceedings of the Conference of the Joint Oceanographic Assembly. FAO, Rome

Submitted: January 12, 2007; Accepted: September 3, 2007

Proofs received from author(s): October 29, 2007 